\title{
津波予報の追跡調查
}

\author{
東京大学地震研究所 羽 鳥 徳 太 郎 \\ (昭和 53 年 10 月 18 日受理)
}

\section{A Follow-up of Tsunami Warning in Japan}

\section{Tokutaro HATORI}

Earthquake Research Institute, University of Tokyo

(Received October 18, 1978)

For the tsunamis generated near Japan and the circum-Pacific seismic zone during the last 26 years (1952-1977), the result of tsunami warning which is reported by the Japan Meteorological Agency is investigated, comparing tsunami prediction with the actual values observed by tide stations. In the East Japan, tsunami warning gave $10 \mathrm{~min}$ or more before the tsuami arrival time. However, in the West Japan and the Japan Sea side, a few tsunami warnings were forestalled, because the arrival times were only several minutes. Height predictions of most tsunamis were successful, but some relatively large tsunamis were underestimated. To be a successful tsunami warning requires not only the information of earthquake magnitude, but also the parameters of the spectra of seismic waves or earthquake moment.

The warnings of distant tsunamis observed in Japan have been successful except the 1952 Kamchatka and 1960 Chile tsunamis. In future, it must be on the watch for large earthquake occurring in these regions.

\section{§1. はじめに}

気象庁では，沿岸住民・臨海施設および船舶などを対象に 1952 年から津波予報業務を始め， 1975 年までの 24 年間に日本近海で拈きた地震に対して 235 回, 環太平洋の外国で拉きた地 震に 52 回, 津波予報を発表してきた [気象庁地震課 (1977 a)]. この間に, 予報区分に変遷もあ つたが，予想される波高に応じて 4 段階に分けて発表されてきた。このよらな警報制度ができ て，津波による死傷者は激減し，多大な成果をあげてきたのである.

最近, 臨海工業施設や沿岸の養殖漁業の急速な発展にともなつて, 数 $10 \mathrm{~cm}$ の小津波でも 影響を受けやすくなり，津波に対する社会的な関心が一段と高まつている．このような社会情 勢の变化に伴ない，従来の津波予報のらち，予報略文とその文意が一致しないことや，ときに は䛊解されることもあつて, 現在の予報技術の水準を考光, 1977 年 2 月から予報規程の 1 部 が改正された。その主な事項は，数 $10 \mathrm{~cm}$ の津波に対し，津波注意報「ツナミチュウイ」と 
「ツナミチュウイカイジョ」を新設し, 津波警報「ツナミオソレ」を廃止した。 また，「ヨワイ ッナミ」を「ツナミ」と変えたことなどである [気象庁地震課 $(1977$ b)].

この改正を機会に，気象庁(1977a) では過去26年間に津波予報を発令した日本近海と，外国 で扣きた地震のカタログを表示した。このなかに，それぞれの地震に対し，津波予報の発令時 間をはじめ，予報管区，予報略文などが細かく明示されている。そこで，これまで津波予報が 発令された津波について，沿岸各地の検潮所などで得た実測值と対比し，発令時間・予測波高 の適正度を追跡調査してみた．この調査から，過去の津波データをふまえて予報の成果を明確 にし，さらに予報精度の向上にむけて津波特性を検討することが本稿の目的である.

\section{§2. 津波予報と観測値}

1952 年から 1977 年までの 26 年間に発令された津波予報について, まず, 地震発生から予 報の発表までの所要時間をみてみよう。気象庁 $(1977 a)$ の調査によれば，所要時間は 7 分から 26 分の間に分布し，全期間の平均值は 15.9 分であつた。そして，この期間の後半に約 1.7 分の時間が短縮されたといら.

そこで, 地震発生から津波予報の所要時間と，各地で観測した津波の到達時間 [例光ば羽鳥 ・小山 (1971)]との差は Fig. 1 のようになる.ここで, 津波予報が発表されてから, その後 波源に最寄りの検潮所で観測された津波初動の到達時間 (単位: 分) との差を, 白丸で示す震央 に「一」記号で示してある。つまり「一」で示す時間後に津波を観測したということで，予報

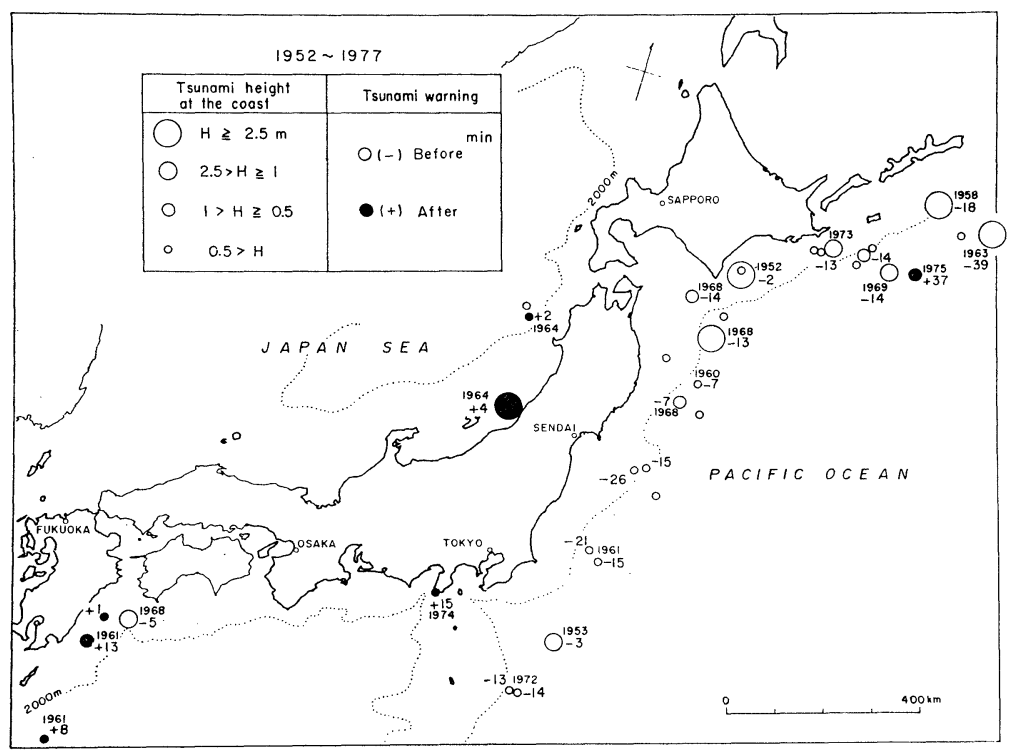

Fig. 1. Difference between tsunami warning time and the observed travel time (unit: $\mathrm{min}$ ). 
が適正であつたことを意味している。これに対し, 沿岸で津波を観測した後に, 津波予報が発 表されたものを黒丸の震央に「十」記号で時間を示し，警報が後手になつたものである．な拉， Fig. 1 には，この 26 年間に観測されたすべての津波をとり上げてある.

図示のように，この期間に三陸から房総沖にかけて，津波が水深 $2,000 \mathrm{~m}$ 付近の沖合に多 くおこつており，予報制度ができた初期のころをのぞけば，警報は津波到達の約 10 分以前に 発令され，かなり成功をおさめてきた，北海道から南千島にかけての津波も，予報時間はきわ めて良好であつたが，ただ $1 つ ， 1975$ 年根室沖津波が後手になり，当時話題をまいた。 これ は， M7.0 の地震で釧路・根室で震度 1 といら微小な地震動であつたが，津波は予想を超え て大きく，花咲港の岸壁に溢れて軽い被害が出た。

一方，南九州の日向灘では津波は沿岸近くに括こり，幸い小規模で実害はなかつたが，後手 になつた警報が目立つ。 日本海側では津波の発生数は少ないが，1964 年の新潟地震・男鹿沖 津波の警報が後手になつた。

つぎに津波予報の波高と，沿岸の実測波高とを比べてみよう。ここで 26 年間に実施されて きた予報区分に対応する波高［気象庁地震課(1977a)］は，次のようである.

a)「ツナミナシ」：文字通り津波を伴わなかつたものと，数 $10 \mathrm{~cm}$ の小津波が含まれていた.

b)「ッナミナシ」・「ッナミオソレ」：津波の高さ（平常の海面からの上昇潮位） $H<0.5 \mathrm{~m}$ $[m=-1]$

c)「ツナミオソレ」・「ヨワイツナミ」: $0.5 \mathrm{~m} \leqq H<1 \mathrm{~m}$, 浅海漁業施設に被害が出る. $[m=0]$

d)「ヨワイッナミ」: $1 \mathrm{~m} \leqq H \leqq 2.5 \mathrm{~m}$, 海岸・船舶に被害. $[m=1]$

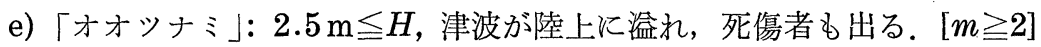

ここで [ ] で示す数字は, 今村・飯田スケールのの津波マグニチュードを表わす.

以上のような津波予報は, 震央距離と地震波の全振幅との関係を示すグラフ, つまり地震 グニチュードから予想して発令されてきたのであるが [気象庁地震課 $(1977 \mathrm{c})$ ]，これを沿岸の 実測波高と比べると Fig. 2 のようになる．ここで，震央を示す丸の大きさは実測波高で区分 し，予報略文を付記してある。そして，予報がうまくいつたものを白丸，波高を過小評価した ものを黒丸，過大視したものを丸に斜線で区分した。

図示のように，この期間に発表された大部分の津波予報は，かなり成功してきた。予報の安 全サイドに立てば，予想波高を過大視することはやむを得ないが，1964 年新潟・1968 年十勝 沖津波など比較的大きな津波が過小評価されており，今後の研究課題になろう.

この 26 年の間に，日本近海の地震について 240 回ほど津波予報が発表されてきたが，これ を地震のマグニチュード別に発表回数をみると Fig. 3 のようになる．M6.5 以下の地震では， 


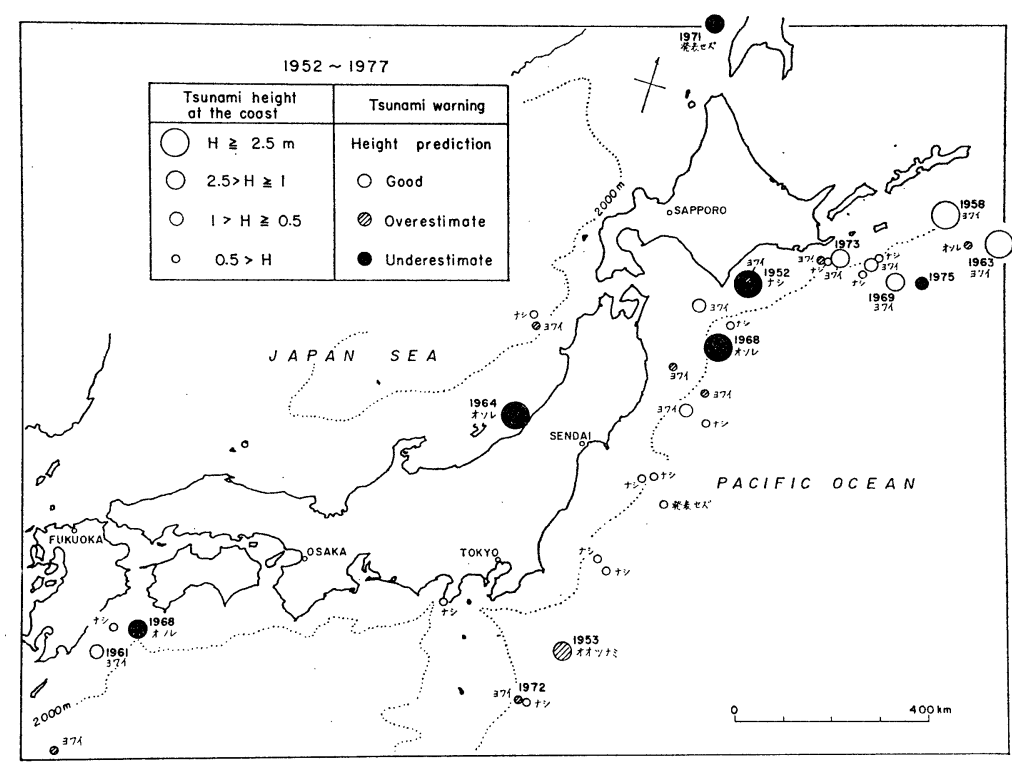

Fig. 2. Comparison with height prediction and the observed tsunami height.

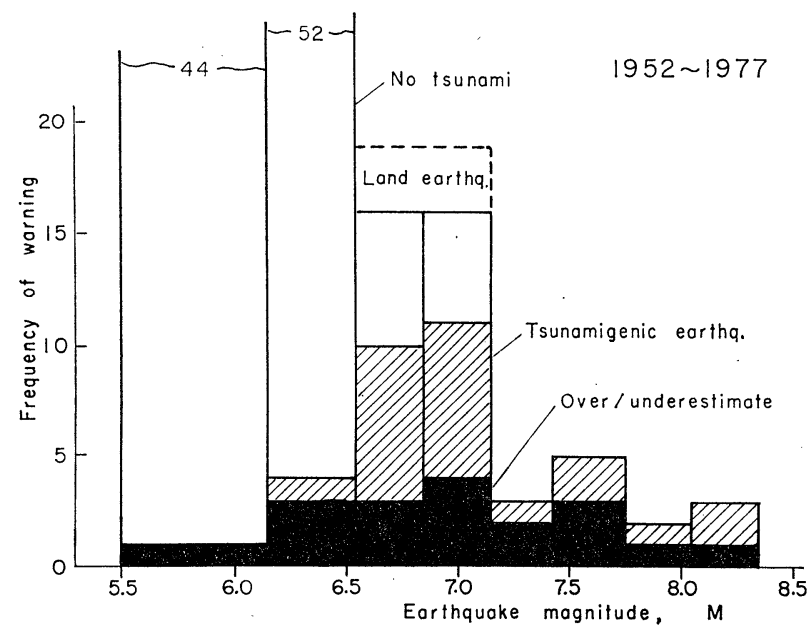

Fig. 3. Relation between earthquake magnitude and frequency of tsunami warning.

「ツナミナシ」といつた予報が当然のことながら多く発表され，実際に津波を観測したものは 斜線で示すように，M7 の地震がもつとも多く，観測漏れを考光れば，発生件数はもら少し増 加するだろう。この期間に拉きた $M 7$ 以下の地震では，いずれも津波は小振幅で社会的な影 響は生じなかつた，問題は $M 7.5$ 前後の地震に伴つた津波で，Fig. 2 に示したように，過小 評価した予報が 2,3 あつた。なお，こうした波高の過大もしくは過小視した津波予報につい て発表時間を調べてみたが，とくに夜間に多いといつた時刻に関係はなかつた。 


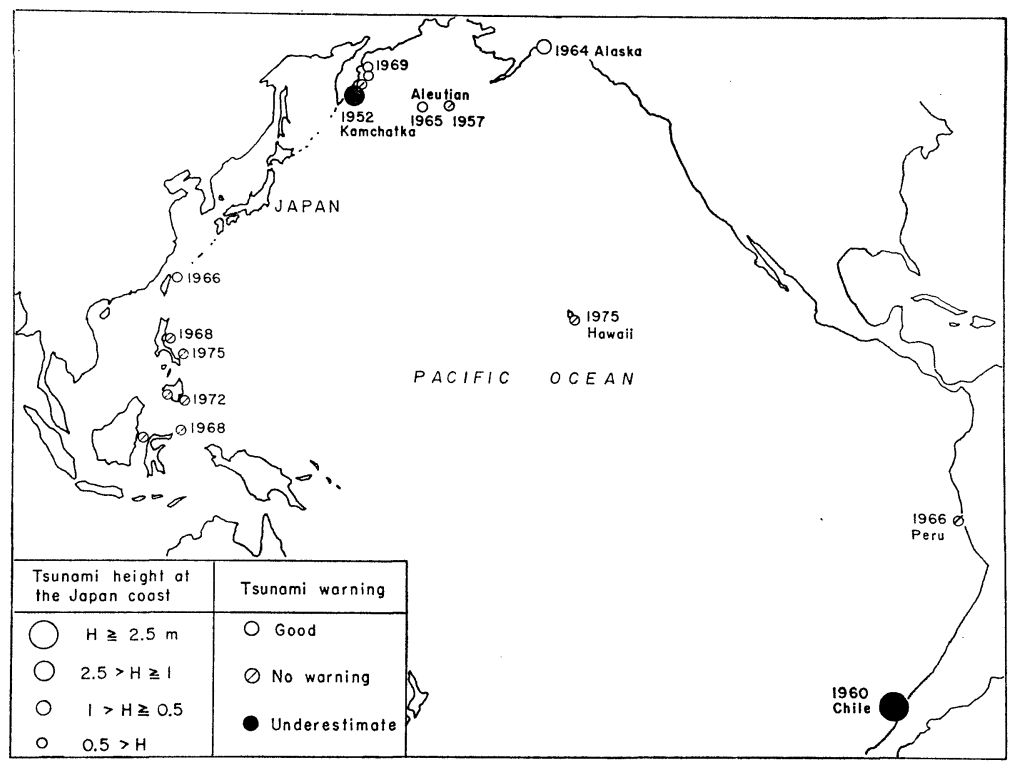

Fig. 4. Warning of distant tsunamis (1952-1976) and the observed heights in Japan.

\section{§3. 外国でおきた遠地津波}

1960 年のチリ津波で予報が後手になつた苦い経験をしたが， 1952 年から 1975 年までの期 間に，環太平洋沿岸で招きた遠地津波の日本沿岸で観測された波高と予報成果は Fig. 4 に示 す通りである。

アラスカ・アリューシャン方面の津波では， 1964 年アラスカ津波などに対して「ツナミオ ソレ」と発表され，沿岸住民に注意を呼びかけた，このとき，大船渡では最高波 $75 \mathrm{~cm}$ ，また 1965 年アリューシャン津波では串本で $55 \mathrm{~cm}$ の津波の高さが観測され，津波予報は良好であ つた. しかし，1952 年カムチャッカ津波では，予報業務が始まつて間もないこともあつて， 予想をこえて北海道・三陸沿岸で沿岸漁業に大きな被害を出し, 予報は後手になつた。今後, カムチャッカ津波に対し, 警戒すべきことを教えている.

フィリピン・インドネシヤ方面で 1970 年前後に多数の津波が和こり, 発生地付近では大き な被害を出したが，西日本沿岸では全振幅，20～ $30 \mathrm{~cm}$ の波高が観測されるのにとどまつた. これらの地震では津波予報は発表されず問題はなかつた。今後, この程度の津波には「ッナミ チュウイ」が適切な予報になると思われるが， $M 8$ 以上の巨大地震に対しては, 警戒が必要で あろら。 


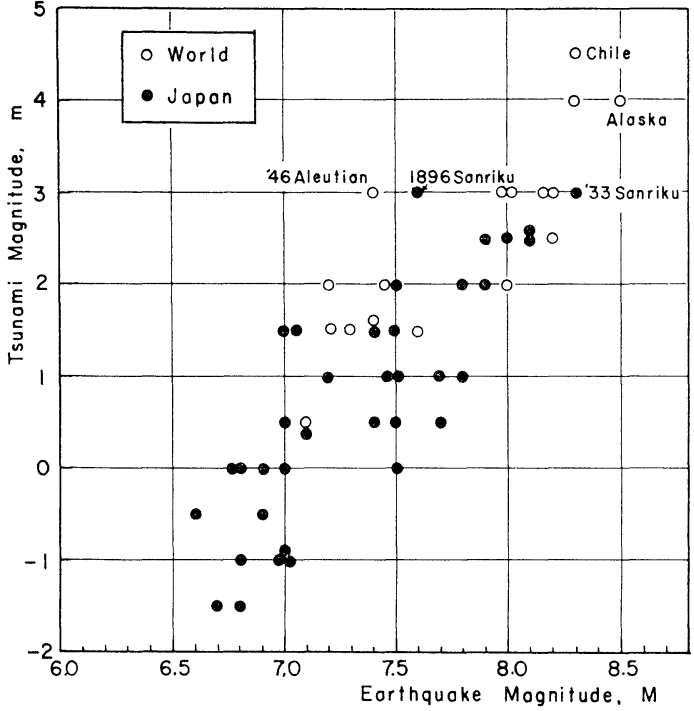

Fig. 5. Relation between earthquake magnitude (20-sec surface-wave magnitude) and tsunami magnitude (Imamura-Iida scale).

\section{§4.むす び}

最近 26 年間に発表された津波予報 に対し，沿岸の観測值と比べた追跡調 査を行なつた。まず，予報の所要時間 に関しては，かなり良好な結果を和さ めてきたが，日本海・日向灘の沿岸で 括こる津波は，伝播時間が 10 分以内 といらこともあつて，予報が後手にな つたものが多い。こうした関東以西の 沿岸付近の津波については，津波予報 は厳しい条件のもとに扮かれて招り， 沿岸住民に予報時間の技術的な限界を 啓発して物くことも必要であろう。

一方，波高の予報についても，かな

り好成績を竦さめてきたが，M7 以下の地震では津波波高を過大視し， $M 7.5$ 前後のものには 過小評価してきた傾向があつた。現在，津波予報は地震規模の情報から波高を予測しているが， 地震と津波との規模の関係は Fig. 5 に示すように，M7.0 7.5 の範囲でとくにバラつきが 大きい(津波マグニチュードが 1 階級あがると，波高は 2.3 倍，津波エネルギーでは 5 倍も大 きくなる)。これは，断層運動の多様性によるもので，現況の地震マグニチュードに依存した 方法ではこれ以上，津波予報の精度向上はむずかしいことを端的に示している，

今後，津波地震の発震機構の研究をふま光，地震波のスペクトルや地震モーメント[羽鳥 1978)]などのパラメータの導入が不可欠であり, こうした情報処理の確立が期待される.

な和，津波予報業務は地震から 20 分以内に発表すれば，規定により“後手”之評価しない のであるが，本文では住民サイドにたつてあえてこの表現を用いた．津波判定からテレビなど 各伝達中枢をへる流れで，報道までに数分もかかるといら問題点もある．観測データが十分集 まりきらない“時間が勝負” の段階で，「ッナミオソレ」といら発表も理解できる。ともあれ 予報制度が出来てから，津波による死傷者が目にみえて激減したことは事実である．津波の多 様性についてまだ不明なことが多い現況で，多大な成果をあげてきたことを高く評価するとと もに，予報担当者に敬意を表したい。

$$
\text { 文献 }
$$

気象庁地震課， $1977 \mathrm{a}$, 津波予報業務の変遷之現況，測候時報，44, 123-170. 
気象庁地震課, $1977 \mathrm{~b}, 2$ 月 1 日から改正される津波予報, 気象, $21,4757$.

気象庁地震課, $1977 \mathrm{c}$, 津波予報図の改正一津波注意報「ッナミチュウイ」の下限について, 験震時 報, 41, 83-94.

羽鳥徳太郎・小山盛雄, 1971, 日本各地に护ける津波の到達時間と津波伝播図, 地震研究所 巢 報, 49, 127-142.

羽鳥徳太郎， 1978, 津波の規模と地震モーメント，地震 $2,31,25-34$. 